\title{
- Fine Structure in Some Infrared Bands of Methylene Halides
}

\author{
Earle K. Plyler and W. S. Benedict
}

\begin{abstract}
The infrared absorption spectra of methylene chloride, methylene bromochloride, and methylene bromide have been studied with a high-resolution grating spectrometer in the region from 1.6 to 2.3 microns. The purpose of these measurements was to determine the molecular constants of these molecules from their spectra. Using the saturated vapor in a cell 60 centimeters long, it was possible to resolve the fine structure in three to five bands of each molecule. All the resolved bands are overtones and combinations of fundamental vibrations localized in the methylene radical, and hence appear at nearly the same frequencies for each molecule. Bands with $Q$ branches (symmetry types $B$ and $C$ ) and without that feature appear. Application of combination relations to all bands of a given molecule yield rotational spacings of the ground state agreeing within 0.5 percent. The spacings, $\left[A^{\prime \prime}-\left(B^{\prime \prime}+C^{\prime \prime}\right) / 2\right]$, are, respectively, for $\mathrm{CH}_{2} \mathrm{Cl}_{2}, 0.955 \mathrm{~cm}^{-1} ; \mathrm{CH}_{2} \mathrm{BrCl}, 0.898 \mathrm{~cm}^{-1}$; and $\mathrm{CH}_{2} \mathrm{Br}_{2}, 0.821 \mathrm{~cm}^{-1}$.

The molecular dimensions cannot be uniquely determined from these data alone, but if tetrahedral angles are assumed, they lead to improbably low values of the $\mathrm{C}$-halogen distance, namely, $1.70 \mathrm{~A}$ for $\mathrm{C}-\mathrm{Cl}$ and $1.83 \mathrm{~A}$ for $\mathrm{C}-\mathrm{Br}$. If the halogen- $\mathrm{C}-$ halogen angle is increased to $112^{\circ}$, as found by electron diffraction, the $\mathrm{C}-\mathrm{Cl}$ distance is in good agreement with the electron diffraction distance $1.766 \mathrm{~A}$, and $\mathrm{C}-\mathrm{Br}$ becomes $1.907 \mathrm{~A}$ in $\mathrm{CH}_{2} \mathrm{Br}_{2}$ and 1.911 in $\mathrm{CH}_{2} \mathrm{BrCl}$.
\end{abstract}

The vibrational bands of methylene chloride, methylene bromochloride, and methylene bromide have been measured in the infrared region, and the bands have been assigned to various modes of motion. ${ }^{1}$ In the spectra of these molecules several overtone and combination bands were observed in the region 1.6 to $2.3 \mu$. This region is well suited for observations with the 15,000-line-per-inch grating instrument, using a lead-sulfide detector. A detailed description of this instrument is given in a previous paper. $^{2}$

The purpose of this investigation was to observe and analyze the rotational fine structure of the overtone and combination bands. From such data, it is possible to draw certain conclusions concerning the interatomic dimensions in the vibrationless ground state of these three closely related molecules, and to demonstrate the marked similarities in the interactions of vibration and rotation in the bands in question.

A tungsten-ribbon-filament lamp, with currents from 35 to 40 amperes, was used as the source. The spectral slit width was about $0.15 \mathrm{~cm}^{-1}$ in the regions of 1.6 and $2.2 \mu$. The absorption cell was $60 \mathrm{~cm}$ in length, and the vapors were allowed to enter the evacuated cell until a saturated state was reached at room temperature. For the more intense bands, the pressure was reduced. The conditions of pressure for each measurement are given in the captions of the figures.

In order to obtain a good accuracy in the measurement of the wavelengths of the rotational bands of these molecules, atomic emission lines of krypton, argon, and neon were superimposed on the recorded chart simultaneously with the recording of the absorption spectra. A fairly large number of lines

1. Earle K. Plyler and W. S. Benedict, J. Research NBS 47, 202 (1951) R P2245. 2 Ea"le K. Plyler and Norman Gailar, J. Research NBS 47, 248 (1951) R P2249. were available, because the first, second, and third orders of certain wavelengths would be superimposed on the first-order region under study. When the standard lines were within $80 \mathrm{~A}$ of each other, it was found that measurements on lines between the standards could be repeated on separate runs to $0.5 \mathrm{~A}$, or $0.1 \mathrm{~cm}^{-1}$, in the $2.2-\mu$ region. All other rotational lines were measured by means of a dispersion curve, which was determined by plotting the known wavelengths as a function of the counter number, and which indicates the position of the grating. From this relationship the wavelength of any line could be determined. Although this method of measurement does not yield as great accuracy as the measurements of the lines, which are close by a superimposed standard, it was found that the wave numbers of any line in a band never varied over $0.3 \mathrm{~cm}^{-1}$ on separate runs, and usually much less than this amount.

Typical experimental results are shown in figures 1 to 4 , inclusive. A number of additional tracings were obtained and measured, revealing additional weaker bands whose fine structure could be interpreted in part, but these are not reproduced. Figures 1 and 2 present four bands of $\mathrm{CH}_{2} \mathrm{Cl}_{2}$; figure 3 , two bands of $\mathrm{CH}_{2} \mathrm{BrCl}$, and figure 4 , four bands of $\mathrm{CH}_{2} \mathrm{Br}_{2}$. It will be noted that the bands of all three molecules are roughly similar in position and structure, and that the fine structure is of two types: (1) bands with a central Q branch, flanked by fairly broad but readily resolved "lines" whose average spacing is approximately $1.64 \mathrm{~cm}^{-1}$ in $\mathrm{CH}_{2} \mathrm{Br}_{2}, 1.80 \mathrm{~cm}^{-1}$ in $\mathrm{CH}_{2} \mathrm{BrCl}$, and $1.91 \mathrm{~cm}^{-1}$ in $\mathrm{CH}_{2} \mathrm{Cl}_{2}$, and (2) bands whose resolved "lines" show identical spacings with those just listed, but with the central Q branch absent.

From the approximate values of the interatomic distances and angles $(\mathrm{C}-\mathrm{H}=1.09 \mathrm{~A}, \mathrm{C}-\mathrm{Cl}=1.76$ 


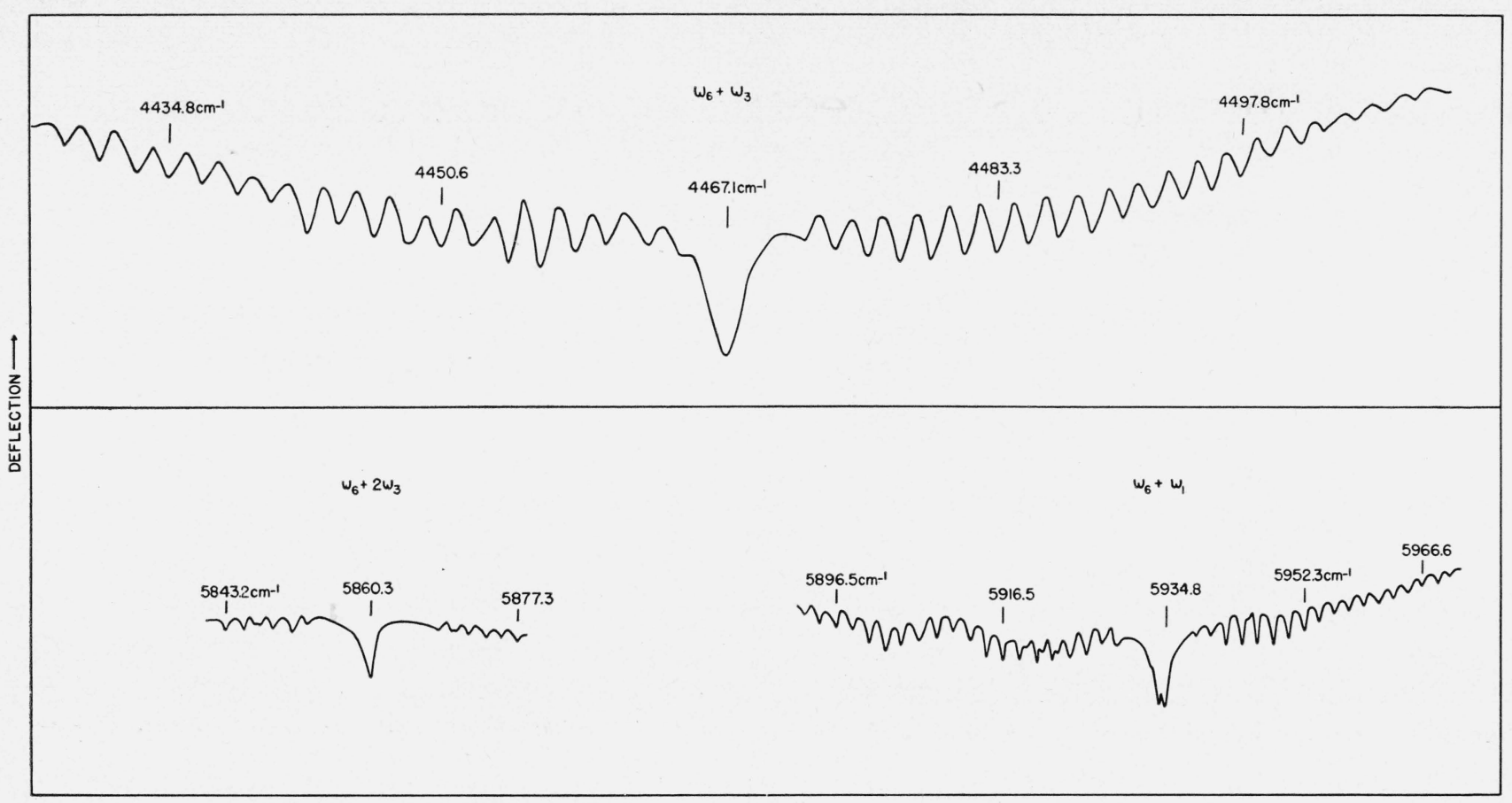

Figure 1. The infrared absorption spectra of $\mathrm{CH}_{2} \mathrm{Cl}_{2}$ vapor for the bands $\omega_{6}+\omega_{3}, \omega_{6}+2 \omega_{3}$, and $\omega_{6}+\omega_{1}$. Saturated vapor, $40 \mathrm{~cm}$, was measured in a $60 \mathrm{~cm}$ cell.

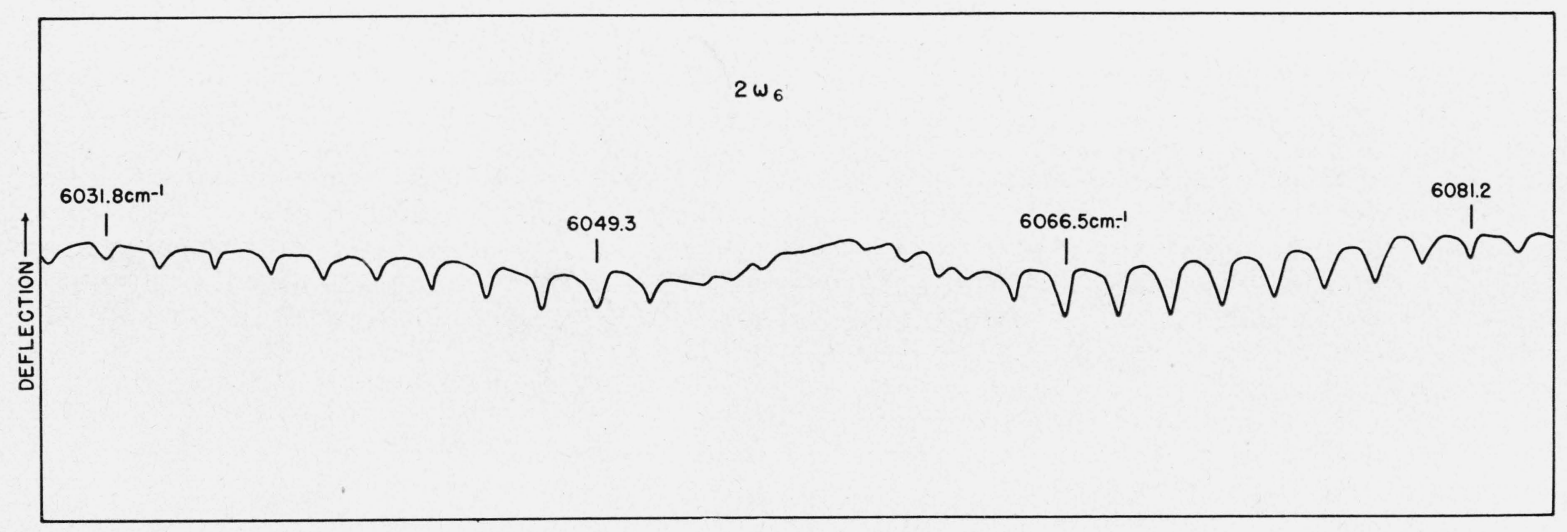

Figure 2. The spectrum of the $2 \omega_{6}$ band of $\mathrm{CH}_{2} \mathrm{Cl}_{2}$.

Saturated vapor at room temperature was used with a $60 \mathrm{~cm}$ cell.

$\mathrm{A}, \mathrm{C}-\mathrm{Br}=1.90 \mathrm{~A}$, tetrahedral angles) characteristic of halogenated methanes, it is possible to calculate trial moments of inertia. For all three molecules the axis of least moment is roughly parallel to the halogen-halogen line (for the symmetrical molecules, it is precisely parallel to this line), and the two other moments are much larger in magnitude and approximately equal. Accordingly, the asymmetry parameter $\delta=(B-C) /(A-C)$ is quite small, taking the values $0.002,0.004$, and 0.010 , respectively, for $\mathrm{CH}_{2} \mathrm{Br}_{2}, \mathrm{CH}_{2} \mathrm{ClBr}$, and $\mathrm{CH}_{2} \mathrm{Cl}_{2}$. Under these circumstances, the rotational structure will approximate that of a symmetric top, and the familiar combination relations for determining the molecular constants may be applied. The two types of observed bands mentioned above are types B and C bands, respectively, of the asymmetric rotor, with the change of dipole moment along the intermediate and greatest axis of inertia, both of which in the limiting case of the symmetric rotor (when $B=C$, or $\delta=0$ ) become "perpendicular" bands. The observed "lines" are $R_{Q}$ and $P_{Q}$ zero branches, each consisting of a number of lines with $\Delta J=0, \Delta K= \pm 1$. These are superposed on the unresolved background of lines with $\Delta J= \pm 1, \Delta K= \pm 1$. The peaks are broadened by several causes (a) the small degree of asymmetry splits the lines of different $J$. This effect is most pronounced for the lines of low $K$, near the band center, and makes it difficult to distinguish the lines with $K<2$; (b) the different moments of inertia 


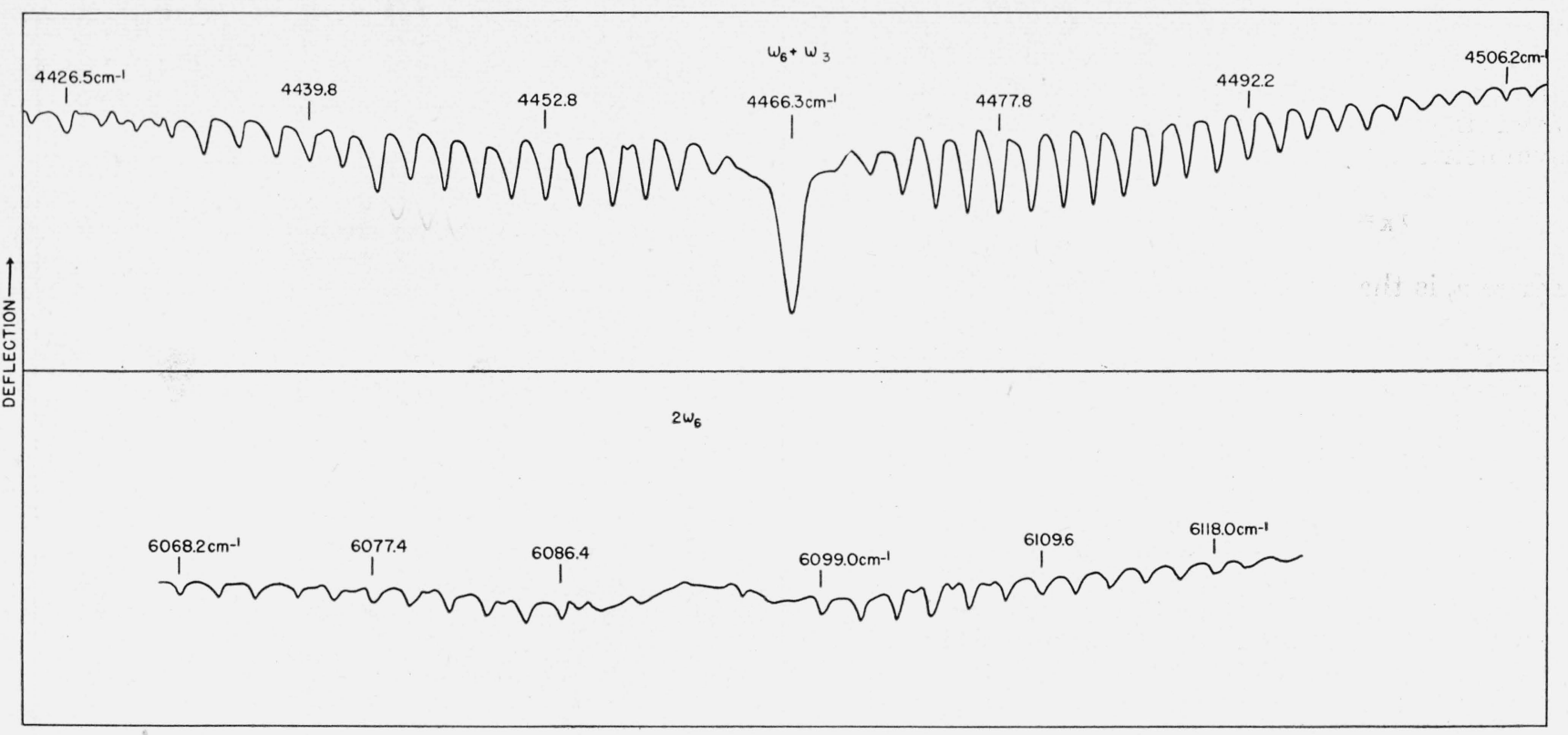

Figure 3. The $\omega_{6}+\omega_{3}$ and $2 \omega_{0}$ absorption bands of $\mathrm{CH}_{2} \mathrm{BrCl}$, with a path of 60 cm and saturated vapor pressure at room temperature.

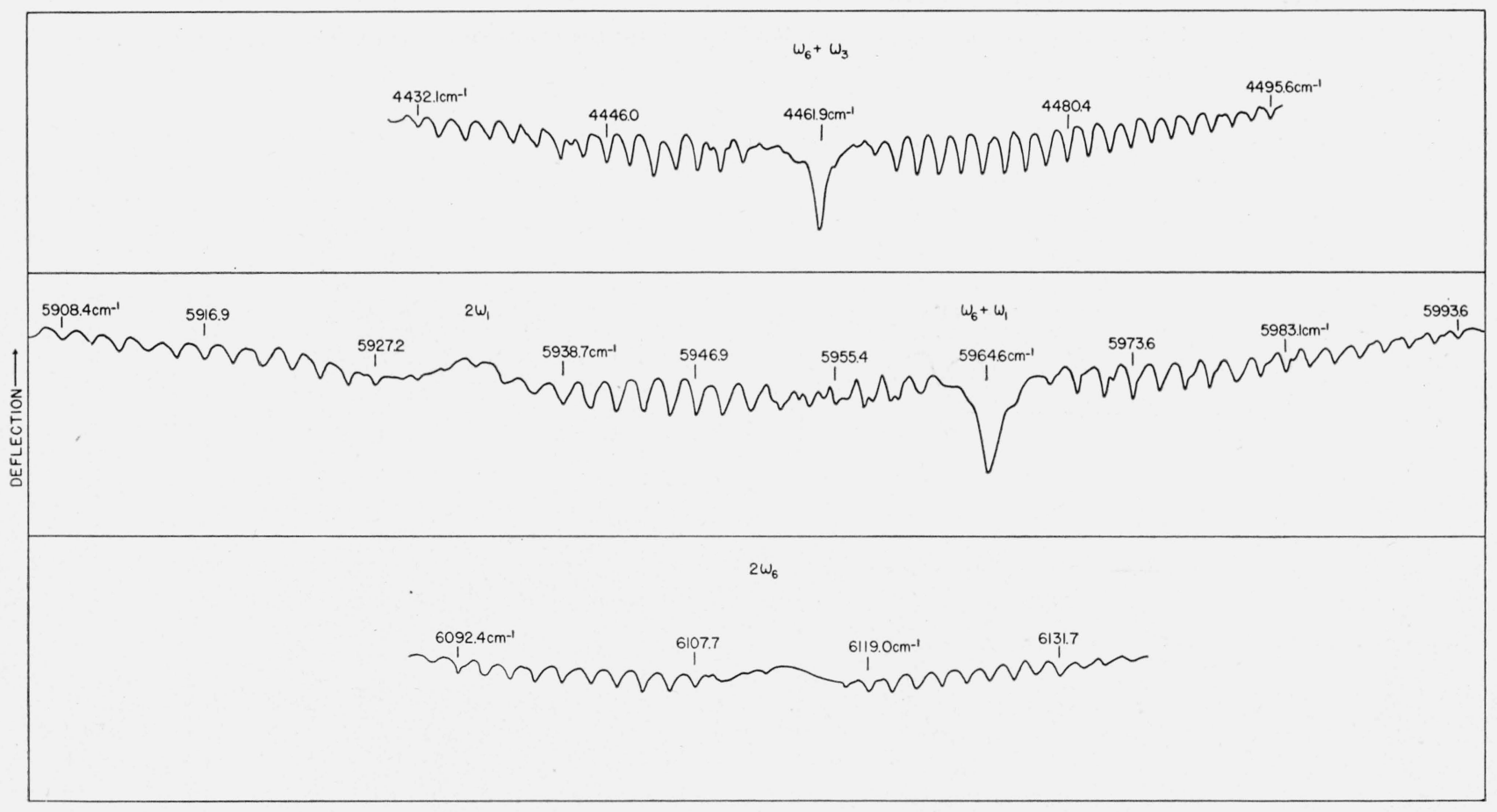

Figure 4. The $\omega_{6}+\omega_{3}, \omega_{6}+\omega_{1}, 2 \omega_{1}$ and $2 \omega_{6}$ absorption bands of $\mathrm{CH}_{2} \mathrm{Br}_{2}$.

The cell length was $60 \mathrm{~cm}$, and the saturated vapor pressure was $44 \mathrm{~mm}$.

in the upper and lower vibrational states, as well as the centrifugal distortions of the molecules, also shift the positions of the lines of different $J$. These effects are most pronounced at high $K$; and (c) the molecules with chlorine and bromine atoms of differant isotopic weights will have slightly different moments of inertia, and hence their lines will be somewhat displaced, leading to broadening. Quin- titative estimates of the importance of all these effects have been made. It is concluded that they are relatively unimportant, and that it is permissible to apply the symmetric rotor formulas to the "lines" of $K>2$, thereby deriving moments of inertia referring to molecules with "average" $\mathrm{Cl}$ and $\mathrm{Br}$ atomic weights.

The wavelengths and wave numbers of the lines

3 
used to derive the band origins and effective rotational constants are given in tables 1 to 3 . The observed values are compared with values calculated from the formula for a perpendicular band of a symmetric top,

$$
\nu_{K}=\nu_{0}+U \pm 2 U K+(U-L) K^{2},
$$

where $\nu_{0}$ is the band origin, $U=A^{\prime}-\left(B^{\prime}+C^{\prime}\right) / 2$,

$L=A^{\prime \prime}-\left(B^{\prime \prime}+C^{\prime \prime}\right) / 2$, and $K$ is the quantum number for the lower state. The + sign is taken for the $R_{Q}$ branch frequency $\nu_{K}^{R}$, and the - sign is for the $P_{Q}$ frequency, $\nu_{K}^{P}$. Since each band of a given molecule has a common lower state, the combination differences $\Delta_{2} F^{\prime \prime}(K)=\nu_{K-1}^{R}-\nu_{K+1}^{P}=4 L K$ should be equal, and should be a linear function of $K$. These differen ces, divided by $K$, are plotted as a function of $K$ in fig ure 5 . It will be noted that the points in figure 5 are essentially constant, and that the agreement of obser ved and calculated frequencies is good. The constants are collected in table 4 . The limits of error cited are esti mated from the scatter of the points, and result fro $\mathrm{m}$ a combination of the experimental error in lccating and measuring the line positions and the theoretical approximations made in reducing data for a nonrigid, slightly asymmetric rotating molecule of compound-isotopic composition by formulas applicable to a rigid, symmetric monoisotopic molecule.

Table 4 also gives other pertinent data for the bands, namely, the band origin $\nu_{0}$ and the vibrational convergence $U-L$. These were obtained from the relation

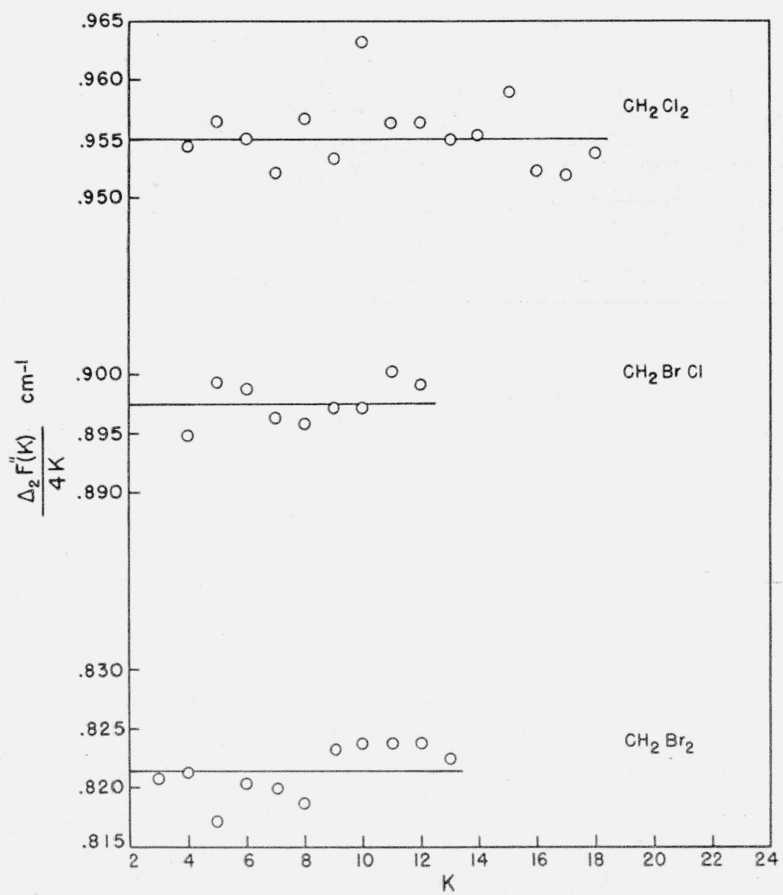

Figure 5. A plot of $\Delta_{2} F^{\prime \prime}(K) / 4 K$ as a function of $K$ for each of the molecules $\mathrm{CH}_{2} \mathrm{Cl}_{2}, \mathrm{CH}_{2} \mathrm{BrCl}$, and $\mathrm{CH}_{2} \mathrm{Br}_{2}$.
$\nu_{0}(K)=\left(\nu_{K}^{R}+\nu_{K+1}^{P}\right) / 2=\nu_{0}+(U-L) / 2+(U-L) K(K+1)$

The straight line resulting from a plot of $\nu_{0}(K)$ against $K(K+1)$ has as slope $(U-L)$ and as intercept $\nu_{0}+(U-L) / 2$.

Included in table 4 are the vibrational data for each band, in terms of the combination, or overtone, frequency involved (the numbering is that used and described in the article cited in footnote 1 ); the rotational type, which confirms this assignment, and the dynamic interpretation of the frequencies in question are also included. It will be noted that the vibrational motions all involve the methylene group; $\nu_{\mathrm{Ha}}$ and $\nu_{\mathrm{Hs}}$ being the asymmetric and symmetric stretching frequencies, and $\delta_{\mathrm{H}_{\mathrm{s}}}$ is the symmetric $\mathrm{CH}_{2}$ deformation. When the combination $\mathrm{s}+\mathrm{a}$ is asymmetric, we have type $\mathrm{C}$; when it is symmetric (2s or $2 \mathrm{a})$, we have type $\mathrm{B}$. The fact that corresponding transitions appear at nearly the same frequency in the three molecules, and with closely corresponding values of the convergence $U-L$, is further indication of how well the vibrational motion is localized in the methylene radical. This has the further result that there is very little vibrational

TABLE 1. Observed and calculated wave numbers of the lines of three bands of methylene chloride $\left(\mathrm{CH}_{2} \mathrm{Cl}_{2}\right)$

The observed values only are listed for the band $\omega_{6}+2 \omega_{3}$.

\begin{tabular}{|c|c|c|c|c|c|c|c|}
\hline \multirow{2}{*}{$K$} & \multicolumn{2}{|c|}{$\omega_{6}+\omega_{3}$} & \multicolumn{2}{|c|}{$\omega_{6}+\omega_{1}$} & \multicolumn{2}{|c|}{$2 \omega_{1}$} & \multirow{2}{*}{$\begin{array}{c}\omega_{6}+2 \omega_{3} \\
\text { Observed }\end{array}$} \\
\hline & $\begin{array}{c}\text { Ob- } \\
\text { served }\end{array}$ & $\begin{array}{l}\text { Calcu- } \\
\text { lated }\end{array}$ & $\begin{array}{c}\text { Ob- } \\
\text { served }\end{array}$ & $\begin{array}{l}\text { Calcu- } \\
\text { lated }\end{array}$ & $\begin{array}{c}\text { Ob- } \\
\text { served }\end{array}$ & $\begin{array}{l}\text { Calcu- } \\
\text { lated }\end{array}$ & \\
\hline & $\mathrm{cm}^{-1}$ & $\mathrm{~cm}^{-1}$ & $\mathrm{~cm}^{-1}$ & $\mathrm{~cm}^{-1}$ & $\mathrm{~cm}^{-1}$ & $\mathrm{~cm}^{-1}$ & $\mathrm{~cm}^{-1}$ \\
\hline$P 20$ & 4428.6 & 4428.6 & 5896. 5 & 5896.1 & -.... & -.... & - \\
\hline 19 & 4430.7 & 4430.6 & 5898.5 & 5898.1 & ...... & & ....... \\
\hline 18 & 4432.9 & 4432.7 & 5900.6 & 5900.2 & -.... & -.... & . \\
\hline 17 & 4434.8 & 4434. 7 & 5902.4 & 5902.3 & - & - & ....... \\
\hline 16 & 4436.6 & 4436.8 & 5904.3 & 5904.2 & . & . & ....... \\
\hline 15 & 4438. 6 & 4438.8 & 5906.6 & 5906. 2 & 6029.6 & 6029.5 & \\
\hline 14 & 4440.7 & 4440.8 & 5903.5 & 5908.3 & 6031.8 & 6031.4 & . \\
\hline 13 & 4442.7 & 4442.8 & 5910.4 & 5910.3 & 6033. 7 & 6033.5 & . \\
\hline 12 & 4444. 6 & 4444.7 & 5912.4 & 5912.3 & 6035. 7 & 6035. 5 & - \\
\hline 11 & 4446.7 & 4446.7 & 5914.5 & 5914.2 & 6037.6 & 6037.5 & - \\
\hline 10 & 4448.9 & 4448.6 & 5916.5 & 5916. 2 & 6039.5 & 6039.5 & \\
\hline 9 & 4450.6 & 4450.6 & 5918.3 & 5918.2 & 6041.5 & 6041.5 & \\
\hline 8 & 4452.5 & 4452.6 & 5920.4 & 5920.2 & 6043.6 & 6043.5 & 5843.2 \\
\hline 7 & 4454.5 & 4454.5 & 5922.2 & 5922.1 & 6045.5 & 6045.5 & 5845.3 \\
\hline 6 & 4456.4 & 4456.5 & 5924.4 & 5924.1 & 6047.4 & 6047.4 & 5847.0 \\
\hline 5 & 4458.3 & 4458.4 & 5926.2 & 5926.0 & 6049.3 & 6049.4 & 5848.7 \\
\hline 4 & 4460.2 & 4460.3 & 5928.0 & 5927.9 & 6051.3 & 6051.3 & 5850.9 \\
\hline 3 & 4462.4 & 4462.3 & 5929.8 & 5929.9 & - & - & 5852.6 \\
\hline 2 & 4464.5 & 4464.3 & ...... & ....... & ........ & ....... & -..... \\
\hline 1 & ...... & . & - & - & 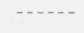 & . & . \\
\hline$R 0$ & & & & & & & \\
\hline 1 & & & & & & - & -.... \\
\hline 2 & 4471.8 & 4471.8 & $\begin{array}{l}5939.3 \\
594 .\end{array}$ & 5939.4 & & & \\
\hline $\begin{array}{l}3 \\
4\end{array}$ & $\begin{array}{l}4473.8 \\
4475.7\end{array}$ & $\begin{array}{l}4473.8 \\
4475.7\end{array}$ & $\begin{array}{l}5941.2 \\
5943\end{array}$ & $\begin{array}{l}5941.3 \\
5943.1\end{array}$ & $\begin{array}{l}6064.6 \\
6066.5\end{array}$ & $\begin{array}{l}6064.7 \\
6066.5\end{array}$ & $\begin{array}{l}5868.0 \\
5870.0\end{array}$ \\
\hline 5 & 4477.6 & 4477.5 & $\begin{array}{l}594.1 \\
594.0\end{array}$ & 5945.0 & 6068.4 & 6038.4 & 5871.7 \\
\hline 6 & 4479.5 & 4479.4 & 5946.6 & 5946.9 & 6070.4 & 6070.2 & 5873.6 \\
\hline 7 & 4481.5 & 4481.4 & 5949.6 & 5948. & 6072.1 & 6072.1 & 5875.5 \\
\hline 8 & 4483.3 & 4483.2 & 5950.4 & 5950. & 6974.1 & 6073.9 & 5877.3 \\
\hline 9 & 4485. 2 & 4485. 2 & 5952.3 & 5952.4 & 6075.9 & 6075.7 & 5879.1 \\
\hline 10 & 4487.0 & 4486.9 & 5954.4 & 5954.2 & 6077.7 & 6077.5 & 5880.9 \\
\hline 11 & 4488.9 & 4488.7 & 5956.2 & 5956.0 & 6079.4 & 6079.3 & \\
\hline 12 & 4490.7 & 4490.6 & 5958.0 & 5957.9 & 6081.2 & 6081.1 & -..... \\
\hline 13 & 4492.6 & 4492.3 & 5959.8 & 5959.7 & 6033.0 & 6982.9 & ....... \\
\hline 14 & 4494.4 & 4494.3 & 5961. 6 & 5961.5 & ....... & ...... & -..... \\
\hline 15 & 4496.1 & 4496.1 & 5963.2 & 5963. 2 & & & \\
\hline 16 & 4497.8 & 4497.7 & 5965. 1 & 5965.0 & . & - & $\ldots$ \\
\hline 17 & 4499.6 & 4499.7 & 5966. 6 & 5966.9 & , n. & ...... & -....- \\
\hline 18 & 4501.5 & 4501. 5 & 5968. 6 & 5963. 6 & - & - n- & - - - \\
\hline $\begin{array}{l}19 \\
20\end{array}$ & $\begin{array}{l}4503.1 \\
4504.8\end{array}$ & $\begin{array}{l}4503.2 \\
4505.0\end{array}$ & 5970.0 & 5970.3 & ........ & - n....... & ........ \\
\hline & & & & & & & \\
\hline
\end{tabular}


TABLE 2. Observed and calculated wave numbers of the lines of two bands of methylene bromochloride $\left(\mathrm{CH}_{2} \mathrm{BrCl}\right)$

\begin{tabular}{|c|c|c|c|c|}
\hline \multirow{2}{*}{$K$} & \multicolumn{2}{|c|}{$2 \omega_{6}$} & \multicolumn{2}{|c|}{$\omega_{6}+\omega_{3}$} \\
\hline & Observed & $\begin{array}{l}\text { Calcu- } \\
\text { lated }\end{array}$ & Observed & $\begin{array}{l}\text { Calcu- } \\
\text { lated }\end{array}$ \\
\hline & $\mathrm{cm}^{-1}$ & $\mathrm{~cm}^{-1}$ & $\mathrm{~cm}^{-1}$ & $\mathrm{~cm}^{-1}$ \\
\hline$P 20$ & -...... & -...... & 4430.2 & 4430.2 \\
\hline 19 & ........ & . & 4432. 2 & 4432.1 \\
\hline 18 & $\ldots . .$. & . & 4434.0 & 4434. 0 \\
\hline 17 & - & - & 4435.8 & 4435. 9 \\
\hline 16 & . & . & 4437.9 & 4437.8 \\
\hline 15 & ........ & & 4439.8 & 4439.7 \\
\hline 14 & & & 4441.5 & 4441.5 \\
\hline 13 & 6068.2 & 6068.4 & 4443. 6 & 4443.4 \\
\hline 12 & 6070.0 & 6070.2 & 4445.4 & 4445.3 \\
\hline 11 & 6071.9 & 6072.1 & 4447.3 & 4447.1 \\
\hline 10 & 6073.8 & 6073. 9 & 4449. 1 & 4449.0 \\
\hline 9 & 6075.7 & 6075. 7 & 4451.0 & 4450.9 \\
\hline 8 & 6077.9 & 6077.4 & 4452.8 & 4452.7 \\
\hline 7 & 6079.1 & 6079.3 & 4454. 6 & 4454.6 \\
\hline 6 & 6081.0 & 6081.1 & 4456.4 & 4456.4 \\
\hline 5 & 6082.7 & 6082.9 & 4458.2 & 4458.2 \\
\hline 4 & 6084.7 & 6084.7 & 4459. 9 & 4460.0 \\
\hline 3 & 6086.4 & 6086.5 & 4461.9 & 4461.8 \\
\hline 2 & $\ldots . .$. & -..... & $\ldots \ldots$ & ........ \\
\hline 1 & - & ........ & ....... & ........ \\
\hline$R 0$ & - & - & , & ........ \\
\hline 1 & ....... & ........ & & 44708 \\
\hline 2 & ......... & - . & $\begin{array}{l}4470.6 \\
4472.5\end{array}$ & $\begin{array}{l}4470.8 \\
4472.6\end{array}$ \\
\hline 4 & 6099.0 & 6099.1 & 4474.3 & 4474.4 \\
\hline 5 & 6100.8 & 6100.9 & 4476.1 & 4476.1 \\
\hline 6 & 6102.6 & 6102. 7 & 4477.8 & 4477.8 \\
\hline 7 & 6104.3 & 6104.5 & 4479.7 & 4479.6 \\
\hline 8 & 6106.1 & 6106. 2 & 4481.5 & 4481.3 \\
\hline 9 & 6107.8 & 6107.9 & 4483.2 & 4483.1 \\
\hline 10 & 6109.6 & 6109. 7 & 4484.9 & 4484.8 \\
\hline 11 & 6111.4 & 6111.5 & 4486.6 & 4486.5 \\
\hline 12 & 6112.9 & 6113.4 & 4488.3 & 4488.3 \\
\hline 13 & 6114.7 & 6115.0 & 4490.0 & 4490.0 \\
\hline 14 & 6116.3 & 6116.8 & 4491.7 & 4491. 7 \\
\hline 15 & 6118.0 & 6118. 6 & 4493.4 & 4493.3 \\
\hline 16 & 6119.5 & 6120.3 & 4495.1 & 4495. 0 \\
\hline 17 & $\ldots \ldots$ & ...... & 4496.7 & 4496. 7 \\
\hline 18 & ........ & ........ & 4498.4 & 4498.4 \\
\hline 19 & $\ldots . .$. & . & 4500.1 & 4500.1 \\
\hline 20 & ....... & $\ldots . .$. & 4501.7 & 4501.8 \\
\hline
\end{tabular}

TABLE 3. Observed and calculated wave numbers of the lines of three bands of methylene bromide $\left(\mathrm{CH}_{2} \mathrm{Br}_{2}\right)$

The observed values only are listed for the band $\omega_{6}+\omega_{1}$.

\begin{tabular}{|c|c|c|c|c|c|c|c|}
\hline \multirow{2}{*}{$\mathrm{K}$} & \multicolumn{2}{|c|}{$2 \omega_{1}$} & \multicolumn{2}{|c|}{$\omega_{6}+\omega_{3}$} & \multicolumn{2}{|c|}{$2 \omega_{6}$} & \multirow{2}{*}{$\begin{array}{c}\omega_{6}+\omega_{1} \\
\begin{array}{c}\text { Ob- } \\
\text { served }\end{array}\end{array}$} \\
\hline & $\begin{array}{c}\text { Ob- } \\
\text { served }\end{array}$ & $\begin{array}{l}\text { Calcu- } \\
\text { lated }\end{array}$ & $\begin{array}{c}\text { Ob- } \\
\text { served }\end{array}$ & $\begin{array}{l}\text { Calcu- } \\
\text { lated }\end{array}$ & $\begin{array}{c}\text { Ob- } \\
\text { served }\end{array}$ & $\begin{array}{l}\text { Calcu- } \\
\text { lated }\end{array}$ & \\
\hline & $\mathrm{cm}^{-1}$ & $\mathrm{~cm}^{-1}$ & $\mathrm{~cm}^{-1}$ & $\mathrm{~cm}^{-1}$ & $c m^{-1}$ & $\mathrm{~cm}^{-1}$ & $c m^{-1}$ \\
\hline $\begin{array}{r}P 20 \\
19\end{array}$ & - . & ....... & -....... & -........ & ......... & $\ldots \ldots$ & -....... \\
\hline 18 & & & 4432.1 & 4432.3 & ........ & - n. & - \\
\hline 17 & & & 4433.6 & 4434.0 & ..... & - non & - \\
\hline 16 & $\ldots$ & $\ldots \ldots$ & 4435.6 & 4435.7 & ........ & ........ & ........ \\
\hline 15 & - & & 4437.4 & 4437.5 & & & \\
\hline 14 & -....... & .... & 4439.1 & 4439. & & & - . . \\
\hline 13 & & & 4440.8 & 4440.9 & 6092.4 & 6092.4 & \\
\hline $\begin{array}{l}12 \\
11\end{array}$ & $\begin{array}{l}5913.6 \\
5915.3\end{array}$ & $\begin{array}{l}5913.8 \\
5915.5\end{array}$ & $\begin{array}{l}4442.6 \\
4444.2\end{array}$ & $\begin{array}{l}4442.6 \\
4444.3\end{array}$ & $\begin{array}{l}6094.0 \\
6095.7\end{array}$ & $\begin{array}{l}6094.0 \\
6095.7\end{array}$ & . \\
\hline & 5916.9 & 5917.2 & 4446.0 & 4446.0 & 6097.4 & 6097.4 & \\
\hline 9 & 5918.5 & 5918.8 & 4447.7 & 4447.7 & 6099.1 & 6099.1 & $\cdots$ \\
\hline 8 & 5920.2 & 5920.5 & 4449.5 & 4449.4 & 6100.8 & 6100.8 & \\
\hline 7 & 5922.0 & 5922.2 & 4451.1 & 4451.0 & 6102.6 & 6102.5 & 5953.8 \\
\hline 6 & 5923.7 & 5923.8 & 4452.8 & 4452.8 & 6104.2 & 6104.2 & 5955.4 \\
\hline 5 & 5925.5 & 5925. 4 & 4454.3 & 4454.4 & 6105.9 & 6105.9 & 5957.2 \\
\hline 4 & 5927.2 & 5927.2 & 4456.0 & 4456.1 & 6107.7 & 6107.5 & 5958.8 \\
\hline 3 & $\ldots$ & - & - & - & - & - & 5960.6 \\
\hline 2 & ........ & ...... & $\ldots$ & $\ldots$ & -....... & -...... & - \\
\hline 1 & - n. & n..... & $\ldots$ & n. & ....... & $\ldots$ & ........ \\
\hline$R 0$ & $\ldots . . .$. & $\cdots$ & - & -..... & -...... & - . & n..... \\
\hline $\begin{array}{l}1 \\
2\end{array}$ & & & 4465 & 4466 & -....... & 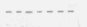 & \\
\hline 3 & 5938.7 & 5938.6 & $\begin{array}{l}4400.8 \\
4467.5\end{array}$ & 4467.6 & 61190 & 6118,9 & $\begin{array}{l}5968.6 \\
5970.4\end{array}$ \\
\hline 4 & 5940.2 & 5940.2 & 4469.0 & 4469.1 & 6120.5 & 6120.6 & 5972.0 \\
\hline 5 & 5942.0 & 5941.8 & 4470.8 & 4470.8 & 6122.0 & 6122.1 & 5973.6 \\
\hline 6 & 5943. 6 & 5943.4 & 4472.4 & 4472.4 & 6123.7 & 6123.8 & 5975. 2 \\
\hline 7 & 5945.2 & 5945.0 & 4474.0 & 4474.0 & 6125.3 & 6125.3 & 5976.9 \\
\hline 8 & 5946.9 & 5946.7 & 4475.5 & 4475.6 & 6126.9 & 6127.0 & 5978.4 \\
\hline 9 & 5948.6 & 5948.2 & 4477.2 & 7744.1 & 6128.5 & 6128.6 & 5980.0 \\
\hline 10 & 5950.3 & 5949.8 & 4478.8 & 4478.8 & 6130.0 & 6130.1 & 5981.6 \\
\hline 11 & 5952.0 & 5951.5 & 4480.4 & 4480.3 & 6131. 7 & 6131.7 & 5983.1 \\
\hline 12 & 5953.8 & 5953.0 & 4481. 9 & 4481.8 & - n. & - & 5984.4 \\
\hline 13 & 5955.4 & 5954.6 & 4483.6 & 4483.5 & -...... & - & - \\
\hline 14 & $\ldots$ & ........ & 4485. 1 & 4485. 0 & ........ & $\ldots$ & , n \\
\hline 15 & ......... & -....... & 4486.6 & 4486.5 & (........ & 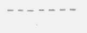 & \\
\hline 16 & . & -....... & 4488. 1 & 4488. 1 & & & - \\
\hline 17 & ........ & ........ & 4489.7 & 4489. 6 & , n........ & $\ldots$ & ......... \\
\hline 18 & - & , n. & 4491. 2 & 4491. 1 & -....... & -....... & (....... \\
\hline 19 & ....... & ......... & 4492.7 & 4492. 6 & $\ldots$ & -....... & -...... \\
\hline 20 & $\ldots \ldots$ & $\ldots$ & 4494. 2 & 4494. 1 & 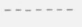 & - & - \\
\hline 21 & ....... &.-- & 4495.6 & 4495.7 & & & \\
\hline
\end{tabular}

TABLE 4. Constants for the molecules of methylene chloride, methylene bromochloride, and methylene bromide

\begin{tabular}{|c|c|c|c|c|c|c|c|c|}
\hline \multirow{2}{*}{\multicolumn{3}{|c|}{$\begin{array}{l}\text { Molecule } \\
L=A^{\prime \prime}-\left(B^{\prime \prime}+C^{\prime \prime}\right) / 2, c \mathrm{~m}-1\end{array}$}} & \multirow{2}{*}{\multicolumn{2}{|c|}{$\begin{array}{c}\mathrm{CH}_{2} \mathrm{Cl}_{2} \\
0.955 \pm 0.003\end{array}$}} & \multirow{2}{*}{\multicolumn{2}{|c|}{$\begin{array}{c}\mathrm{CH}_{2} \mathrm{ClBr} \\
0.898 \pm 0.003\end{array}$}} & \multirow{2}{*}{\multicolumn{2}{|c|}{$\begin{array}{c}\mathrm{CH}_{2} \mathrm{Br}_{2} \\
0.821 \pm 0.003\end{array}$}} \\
\hline & & & & & & & & \\
\hline Band & Type & Vibration & $U-L$ & $v_{0}$ & $U-L$ & $v_{0}$ & $U-L$ & $v_{0}$ \\
\hline $\begin{array}{r}\omega_{6}+\omega_{3} \\
\omega_{6}+\omega_{1} \\
2 \omega_{6} \\
2 \omega_{1} \\
\omega_{6}+2 \omega_{3}\end{array}$ & $\begin{array}{l}\mathrm{C} \\
\mathrm{C} \\
\mathrm{B} \\
\mathrm{B} \\
\mathrm{C}\end{array}$ & $\begin{array}{c}v \mathrm{Ha}+\delta \mathrm{Hs}_{\mathrm{s}} \\
v \mathrm{Ha}+v \mathrm{Hs} \\
2 v \mathrm{Ha} \\
2 v \mathrm{HF}_{\mathrm{s}} \\
v \mathrm{Ha}+2 \delta \mathrm{Hs}\end{array}$ & $\begin{array}{r}0.004 \\
-.003 \\
-.004 \\
0\end{array}$ & $\begin{array}{c}c m^{-1} \\
4467.2 \\
5934.6 \\
6057.0 \\
5858.0\end{array}$ & $\begin{array}{c}-0.004 \\
-0.003 \\
-0\end{array}$ & $\begin{array}{c}c m^{-1} \\
4466.3 \\
6090.9 \\
\end{array}$ & $\begin{array}{r}0.004 \\
-.004 \\
-.004\end{array}$ & $\begin{array}{c}\mathrm{cm}^{-1} \\
4461.7 \\
5964.8 \\
6113.4 \\
5932.9 \\
\end{array}$ \\
\hline
\end{tabular}

isotopic shift due to the $\mathrm{Cl}$ or $\mathrm{Br}$ isotopes. Calculation predicts that the $\nu_{\mathrm{H}}$ 's should be shifted by less than $0.01 \mathrm{~cm}^{-1}$, and $\delta_{\mathrm{H}}$ by less than $0.1 \mathrm{~cm}^{-1}$, which is in accordance with the failure to observe any isotopic shifts.

The determination of a single ground-state rotational constant, $A^{\prime \prime}-\left(B^{\prime \prime}+C^{\prime \prime}\right) / 2$, in this work cannot, of course, lead to a determination of the molecular dimensions. These depend on four or five param- eters. The data do, however, restrain the limits within which the dimensions must lie. The $\mathrm{C}-\mathrm{H}$ distance and HCH angle do not appreciably affect the moments, and may safely be taken as $1.093 \times 10^{-8}$ $\mathrm{cm}$, as generally observed in methane and its derivatives, and tetrahedral HCH angle. The observed $A^{\prime \prime}-\left(B^{\prime \prime}+C^{\prime \prime}\right) / 2$ then leads to a unique relation between XCX angle and $\mathrm{C}-\mathrm{X}$ distance for $\mathrm{CH}_{2} \mathrm{Cl}_{2}$ and $\mathrm{CH}_{2} \mathrm{Br}_{2}$. Assuming tetrahedral angles, the 
$\mathrm{C}-\mathrm{Cl}$ and $\mathrm{C}-\mathrm{Br}$ distances would be, respectively, 1.70 and $1.83 \mathrm{~A}$, improbably low values. If the angle is widened to $112^{\circ}$, as found by electron diffraction, ${ }^{3}$ the $\mathrm{C}-\mathrm{Cl}$ distance becomes $1.766 \mathrm{~A}$, and $\mathrm{C}-\mathrm{Br}$ is $1.907 \mathrm{~A}$ in $\mathrm{CH}_{2} \mathrm{Br}_{2}$. With this same value, $112^{\circ}$ for $\mathrm{BrCCl}$, and $1.766 \mathrm{~A}$ for $\mathrm{C}-\mathrm{Cl}$, the $\mathrm{C}-\mathrm{Br}$ distance is $1.911 \mathrm{~A}$. Our fine-structure spacings are thus entirely consistent with the electron diffraction data, and confirm the fact that the halogen - C-halogen angle is appreciably greater than tetrahedral. Since the completion of this work, a preliminary account of a complete structural determination of $\mathrm{CH}_{2} \mathrm{Cl}_{2}$ from microwave spectra has been reported. ${ }^{4}$ The structural conclusions reached are the same as ours, and the $A^{\prime \prime}-\left(B^{\prime \prime}+C^{\prime \prime}\right) / 2$ obtained from these more accurate data, $0.96097 \mathrm{~cm}^{-1}$, is in reasonable agreement with the results reported here.

${ }_{4}$ W. D. Gwinn and R. J. Myers, Symposium on Molecular Structure, Ohio State University, June (195i).

Washington, April 1, 1952. 